\title{
The Influence of Emotional Progression Factors on Adjustment to Loss and Grief on Kenyan Orphaned Secondary School Students
}

\author{
Judith Anyango Owaa \\ Jaramogi Oginga Odinga University of Science and Technology \\ *Dr Peter J.O. Aloka \\ Department of Psychology, JaramogiOgingaOdinga University of Science and Technology, \\ P.O. BOX 210, Bondo, 40601, Kenya \\ jairopeteraloka@yahoo.com \\ Dr Pamela Raburu \\ Department of Psychology, JaramogiOgingaOdinga University of Science and Technology
}

\author{
Doi:10.5901/mjss.2015.v6n4s3p190
}

\begin{abstract}
The purpose of the study was to determine the influence of emotional progression factors on adjustment to Loss and Grief on orphaned Kenyan secondary school students. The study was informed by Erikson's Psychosocial Theory of Human Development. Mixed method research approach was used and with it, concurrent triangulation design was adopted. The target population consisted of 47 schools, 20 focus group discussion students, 10 personal interviews and 1,245 Form 3 orphaned students from public secondary schools in Kisumu Central Sub-County of Kenya. A sample size of 453 students from 15 secondary schools were sampled for the study using stratified random sampling technique. Reliability of the instruments was ascertained through a pilot study of $9 \%$ of the population that did not participate in the final study. Internal consistency was also used to determine the reliability of questionnaires and coefficient values of $r=0.0771$ was reported for the questionnaire. Face validity of the instruments was ascertained by pilot testing the questionnaires and also by seeking expert judgment by university lecturers. Data was collected by use of questionnaires, in-depth interviews and focus group discussions. Quantitative data was analyzed using both descriptive and inferential statistics. Qualitative data was analyzed using thematic framework. Trustworthiness of qualitative data was ensured by analyzing the framework as fronted by Lincoln \&Guba (1985). The study findings revealed that emotional progression factors effected adolescents' adjustment to loss and grief. Respondents were positive about death and they concluded that death was not their greatest fear, yet, the feeling of being loved generated more positive feelings among adolescent respondents who said that the sense of being loved made them happy.
\end{abstract}

Keywords: emotional progression factors;adjustment; Loss and Grief; orphans; secondary school; students.

\section{Introduction}

Adolescents have to inevitably perform the duty of maneuvering their lives through developmental progression (Taylor, 2011). Aaron (2005) augments that adolescents experience catastrophic crises as they trudge through this stage. Emotionally, help.fortroubledteens, (2014) records that; adolescence primarily is a time of internal turmoil and upheaval. In America, belief systems development and transition modes in to adulthood acted as huddles for adolescents (Currie \& Thiele, 2009). Adolescents found it emotionally hard to be in sync with societal expectations adherence to family rules, regulations and norms. In Italy, consumption of alcohol and illicit drug use were ways in which adolescents thought they found emotional satisfaction in self and others (Santrock, 2007). While Darwin believed that adolescence was a representation of our human ancestors' shift from being primitive to civilized (Hall, 2006), Freud argued that, the psychological disturbances associated with adolescence were biologically based and emotionally activated as quoted in (Hoffnung, 2007). Berk, (2009) \& Gross (2005) concur that, many adolescents make poor or erratic choices due to the varied factors that govern their progression.

In South Africa, adolescents spent most of their time emotionally attached to other adolescents on media as seen in (Scharf \& Shulman, 2010). In Kisumu Central Sub-County of Kenya, counselling organizations recorded pent up feelings as one of the outstanding issues in adolescence progression (Okello, 2008). The study by Owaa, (2010) also 
reported that, $56 \%$ of adolescent orphans that requested for therapy were not able to cope with developmental issues and were looking for whom to talk with to be able to process their loss. Kenya Institute of Professional Counsellors (KIPC), recorded that $63 \%$ of truancy in secondary schools could be traced to orphans. Agape Counselling and Training Services (ACTS), noted with concern that in a survey of 60 schools in which they conducted peer counselling training in the then Nyanza province, $74 \%$ of students that saw the need to find therapy were bottled with unprocessed loss and grief (Owaa, 2010). This therefore implies that the orphaned adolescent students have the challenge of adjustment to loss and grief in the presence of emotional progression factors. NASCOP, 2012 also noted that many adolescents have to cope with loss and grief due to new HIV infections that had increased among married couples at a rate $14-19 \%$. This therefore means that more adolescents are forced to walk the tight rope of bearing the loss of their loved ones with no one to help them begin the adjustment process to near-normalcy again. Leek, (2011) observed that this can be catastrophic and thereby drain adolescents emotionally and in the long run interfere with progression factors and adjustment to loss and grief. Unfortunately, socio-cultural setups in the society are more of barriers and not enablers, thereby acting as constraints in emotional recovery from loss. Okello, 2008 noted that significant others are in denial as an ego defense mechanism and limited capacity building amongst societies in Kisumu Central Sub-County act as barriers to therapy for adolescents was a fact on the ground that needed to be addressed. The study by Owuor \& Mauta, (2011) revealed that socio-cultural and family set ups are wanting in the provision of the much needed therapy, the present study intends to fill the gap by finding out if within the society there are laid down structures that could emotionally cushion adolescents adjusting to loss and grief. Choudhury, Blakemore \& Charman, 2006 therefore defined emotional progression factors refer as the act of adolescents learning the value laden skill of expressing their feelings in appropriate ways, it could reflect when adolescents are upset or worried, happy or excited.

British Association of Counselling \& Psychotherapy (2009) argued that adaptation strategies and techniques may provide adolescents with emotional ability to be able to believe in themselves and find solace during turmoil periods that the present study wishes to find out. Gray \& Tindall, (2008) also added that, the already grim situation, midwifed by adolescent progression factors, may be worse for adolescents who have suffered loss, are grieving, unattended and are struggling to adjust. Therefore, the present study sought to determine the influence of emotional progression factors on adjustment to Loss and Grief on orphaned Kenyan secondary school students.

\section{Theoretical Framework and Literature Review}

\subsection{Theoretical Framework}

This study was informed by Erik Erikson's (1968) Psychosocial Theory of Human Development, and Kübler-Ross Cycle model (1969) of loss and grief. According to Erikson, the social set up of an individual had greater influence on him than his primitive impulses (Gross, 2005). Erikson's Psychosocial theory of Human Development was entrenched in his book "Identity: Youth and Crisis (1968)" He believed that as a person grew, his greatest concern, (consciously or otherwise) was Identity. He segmented aperson's life span in to eight paired stages which he called: Basic trust vs. basic mistrust (hope), Autonomy vs. Shame (will), Initiative vs. Guilt (purpose), Industry vs. Inferiority (competence), Identity vs. Role Confusion (fidelity), Intimacy vs. isolation (love), Generativity vs. stagnation (care) and Ego integrity vs. despair (wisdom) (Engler, 2008). The stages that mirrored a person's life span were pegged to favourable outcomes which he termed as 'personality virtues'. In the event that a virtue was missed at a particular stage, Erikson said that a person got in to an Identity Crisis.Erikson's theory became suitable for adolescents who were at the center of the present study. He explored three aspects of identity: the ego identity (self), personal identity (the personal idiosyncrasies that distinguish a person from another and social/emotional identity (the collection of social roles a person might play). Eriksonian theory considered the impact of external factors, parents, guardians, siblings and society on personality development from childhood to adulthood on these three identity aspects. It is in this respect that this present study deemed the theory as adequate to help students who had been emotionally influenced by the impact of external factors, parents, guardians, siblings and society on personality and progression development at a time that they are trying to maneuver developmental milestones.

\subsection{Literature Review}

Ashwalt, (2011) in a case study report in USA, looked at viewsof relative magnitudes and patterns of emotional change over a period of three years' of postloss grief indicators. The study findings were that, acceptance was the most frequently endorsed item and yearning was the dominant negative emotion grief indicator from 1 to 24 months of 
postloss. The 5 emotion grief indicators achieved their respective maximum values in the sequence - disbelief, yearning, anger, depression, and acceptance as predicted by the stage theory of grief. The study therefore concluded that emotional identification of the normal stages of grief following a death from natural causes enhanced understanding of how the average person emotionally processed the loss of a family member.However, the reviewed study that focused on relative magnitudes and patterns of emotional change over a period of time and on an unspecific classification of neither gender nor age was in the USA and not in Kenya. The present study filled literature gap by looking at gender differences in adjustment to loss and grief in Kisumu Municipality, Kenya.

Motari, (2006) in a focus group discussion studied the perspectives and indigenous volitions of death and its origin among the Communities of Western Kenya. The study findings indicated that $40 \%$ (45 participants) agreed that their communities have perspective and indigenous volitions of death and its origin; $30.6 \%$ (30 participants) associated death with punishment by a supreme being; $23.5 \%$ (21 participants) augmented that death was a form of destiny which was in the hands of their ancestors and evil spirits as well. A minority of 17.9\% (16 participants) were undecided as to a definite cause of death in the community. Instead they cited volitions that were tied to specific communities and not general ones. They argued that some deaths had historical, spiritual, sacrificial and family connotations. This reviewed study focused on perspectives and indigenous volitions of death and its origin among Communities but did not address the emotions of the persons left behind to adjust to loss and subsequent grief. So the current study filled the gapin literature by studying in detail emotional progression factors that may aggravate adjustment to grief for adolescents. Moreover, the reviewed study was qualitative in nature while the present study gave comprehensive findings since the study adopted a mixed method approach that analyzed both quantitative and qualitative data.

Nyangaga, (2007) conducted a baseline study of adolescents in school leadership. She explored students' impetus, experiences and emotions in becoming school leaders. A study population of 142 opinion leaders from selected Kenyan schools participated. Using Achievement-Related Attribution, (self-efficacy), with variation scales of optimistic, successful, observant, hopeful and skeptical. The study reported that, $49 \%$ of those who succeed as school leaders are intuitively optimistic, $09 \%$ wanted to be successful, $13 \%$ were keen observers of what was done and so they learnt, $23 \%$ were students who hoped to do it right while $06 \%$ of those studied were skeptical about their capacity as leaders. The study findings were that, optimistic students performed better in leadership and very few students saw leadership as being successful while a good number observed others and learnt. Many students hoped to be good leaders and a relatively small fraction were skeptical of school leadership. The study focused on a five tier leadership variation scales in Kenya while the present study focused on Kisumu Municipality. Also, the study was purely quantitative while the present study filled the literature gap by giving mixed method design that produces hybrid results.

In another survey conducted by Cerel, Mary, Verducci, Ronald \& Weller, (2006) based on Downe-Wamboldt's content analysis stage theory of 1992 on grief. The study documented the heavy reliance of medical therapy while adjusting to loss and grief. The survey investigated particular aspects of, or diagrammed changes in, grief reactions over time that found five divergent grieving trajectories from preloss to 18 months postloss that included: common grief, chronic grief, chronic depression, improvement during bereavement, and resilience. These were the common patterns in the study of 201 voluntary participants who had been through loss and were grieving. The study used data from a sample of community-based bereaved individuals to examine the course of common grief, chronic grief, chronic depression, improvement during bereavement, and resilience from 1 to 18 months of postloss. However, the reviewed study did not explicitly test and ascertain whether the normal course of adjustment to a natural death, progressed through common grief, chronic grief, chronic depression, improvement during bereavement, and resilience. The present study therefore endavoured to showcase the component of strategies for adjustment to loss and grief, and not the heavy reliance of medical attention to loss therapy.

Bonanno, Wortman, \& Lehman, (2007) conducted a case studyon Alaska adolescents and explored emotional progression aspects of loss and grief. The findings revealed that, a large majority of interviewees were emotionally traumatized during the interview. Furthermore, some of them perceived their loss as punishment, revenge or compensation for ills committed. The findings in addition indicated that, many children, and youth therefore went through psychological torture that could have otherwise been avoided. The results also indicated that, challenges of adjustment to grief encountered were: cultural, historical, religious mythical, age and gender oriented. Results also showed that adolescent girls faced greater obstacles in adjusting to loss and grief. The reviewed study however was based in Alaska and not Kenya and had quantitative data only. The present study filled the literature gap by providing both quantitative and qualitative results. Petersen, (2012) research study interviewed eight Liberian refugees who were children or adolescents during the war in order to explore their experiences and resilience. The findings of this research showed that amidst warfare, trauma and loss, the refugees exhibited resiliency, macro-level social work, and cross-cultural social work. The reviewed study however was on refugees and not adolescents in Liberia and not in Kenya. The present study 
therefore filled the literature gap by providing information on adolescent students that are adjusting to loss and grief.

Robyn, (2014) conducted a survey showing how Ebola orphans in West Africa are struggling to cope with loss and grief. The findings showed that $89 \%$ of the adolescents were collected at the church due to the emotional toll of Ebola outbreak. A further scrutiny on the reasons showed that $51 \%$ of the adolescents were orphaned by Ebola and had been sent away by landlords. Another $27 \%$ had homes but could not bear the pain any longer and $13 \%$ only felt safe in church. Hunger and death scare was responsible for $9 \%$ of the adolescents who were at the church. Moreover, $86 \%$ of the adolescents said that at that point in time, education was not important; their loss was grave and decisive. However, the survey conducted was in Liberia and on children while the present study was in Kenya and was on adolescents in schools that had adjusted to loss and grief.

Abdulaziz, \& Umar, (2015) conducted a survey with survivors that fled Yola and Kano towns of Nigeira after Boko Haram's deadliest attack that left more than 2,000 people deadThe findings revealed that $91 \%$ of the survivors had to walk over strewn dead bodies to find safe cover while $29 \%$ of them were not able to sleep or be still as they were traumatized. Also, $53 \%$ of the respondents cried uncontrollably at intervals. The survey also observed that $80 \%$ of the respondents were not interested in food. The findings revealed that respondents were fixated at the horror and human butcher that they experienced hence their emotional manifestations. The findings also revealed that when emotions run deep, physiological needs like hunger are relegated to second place. However, the reviewed study was focused on Nigeria while the present study was based on Kisumu Municipality, Kenya. The present study therefore filled the research gap by focusing on adolescence emotions as was experienced by adolescents that had suffered loss and were grief.

\section{Research Methodology}

\subsection{Research Design}

The researcher adopted concurrent triangulation model where both quantitative and qualitative data was collected. In this model therefore, both quantitative and qualitative data collected was analyzed at the same time of the research study. The researcher therefore gave equal priority to both components (Murdin, 2009). Ideologically, priority was slotted equally between the two methods, but practically as findings were analyzed priority tilted to qualitative approach (Creswell \& Plano-Clark, 2011).With regards to treating both data, triangulation was ably adopted (Stake, 2010). Triangulation refers to a combination of methodologies in a study of the same phenomenon (Rothbauer, 2008).

\subsection{Study Participants}

Target population for the present study comprised of 1245 Form three partially or totally orphaned students in public secondary schools in Kisumu Central Sub-County-Kenya.A sample size of 453 secondary school students from 15 schools were selected to participate in this study using stratified random sampling technique. The sample size of 453 students for quantitative sample was considered appropriate since according to Bragg, (2011) who noted that one third of a population was an adequate sample, whose information can be deduced for the general population. A sample of 10 partial or total orphaned students were selected from the sampled schools for interviews using purposive sampling technique. According to Lucas (2013), purposive sampling technique is primarily used in qualitative studies was defined as selecting units (e.g., individuals, groups of individuals, institutions) based on specific purposes associated with answering a research study's questions.

\subsection{Research Instruments}

Emotional Progression Factors Questionnaire for students is an instrument that was used for quantitative data collection on adolescents' personality, while interviews were used to collect qualitative data. In depth-interviewing was employed in the present study because it enabled the researcher to understand and interpret emotional reality through meanings that the respondents attached to their career experiences (Punch, 2010). The EPFQ was self explanatory and student respondents reflected on their inner feelings to be able to fill the questionnaire. The response format was designed in a 5point Likert scale: Strongly Agree, Agree, Undecided, Disagree and Strongly Disagree.

To ascertain the usability of the instrument, the researcher adopted expert judgment that was lecturers of Jaramogi Oginga Odinga University of Science and Technology from the department of Education psychology for verification and feedback during seminar presentations. In the present study the internal consistency of the instruments was obtained by computingCronbach alpha (a) using SPSS Version 20. Averages of all possible 'split-half' correlation coefficients resulting 
from different ways of splitting the scale items were computed. The researcher also computed the reliability for multi-item opinion questions. The items were tested using Cronbach alpha and it gave an overall reliability of 0.788 . The result was an indication that the present internal consistency which was above the recommended reliability of $0.6 ; a>0.6$ indicated satisfactory internal consistency reliability for the multi item opinion questions. Quantitative data was collected using questionnaires from 345 students while qualitative data was collected using 10 personal interviews and focus group discussions were conducted with 20 semi and total orphans.

\subsection{Data Collection Procedures}

Data collection procedure began after the proposal had been accepted and approved by the university supervisors. An introductory letter was acquired from Board of post graduate studies of JaramogiOgingaOdinga University. Permission to proceed to the field and collect data was sought from the National Council of Science and Technology. Ethical issues were considered. This included privacy of possible and actual participants, voluntary nature of participation, consent and possible deception of participation and maintenance of confidentiality of data provided. Questionnaires were issued to sampled students while interviews were held with a few of them and the responses tape recorded. Quantitative data was collected using questionnaires from 345 students while qualitative data was collected using 10 personal interviews. Focus group discussions were conducted with 20 semi and total orphans to collect qualitative data.

\subsection{Data Analysis}

Quantitative analyses involved the use of descriptive and inferential statistics. The inferential statistics allowed researcher to present data obtained in statistical format so as to facilitate identification of important information derived from research questions that made data analysis more meaningful. Quantitative data was analyzed by statistical tests such as independent sample tests.In the present study, raw data that was produced from 20 tape recorded views and 10 personal interviews that were transcribed and read over and over so as to check for any incomplete, inconsistent or irrelevant data (Mason, 2010). Transcriptions were analyzed thematically using the process described by Creswell \& Plano-Clark, (2011) in their deliberations.

\section{Findings and Discussion}

The study found out the relationship between emotional progression factors and adjustment to loss and grief on orphaned secondary school students in Kisumu Central Sub-County. This objective was achieved, first, by testing the null hypothesis that: 'There is no statistically significant relationship between emotional progression factors and adjustment to loss and grief among orphaned secondary school students' and then, second, the researcher compared how individual adolescents indicated their response to emotional progression factors as they adjusted to loss and grief. Emotional progression factors which refer to extraversion and introversion, are typically viewed as two differing extremes in personality. Introverted individuals exhibit attitude-type characterised by orientation in life through subjective focus on one's inner psychic activity while extraversion manifests an attitude type characterised by concentration of interest on the external object (Charach et.al, 2011; Tharp-Taylor et.al, 2012). Emotional progression factors were believed to have a bearing to the process of adjustment to loss and grief.Adolescence emotional progression factors could exhibit themselves in a manner that may be viewed with mixed feelings by the adolescents themselves. Coupled with adjusting to loss and grief for adolescents who already have new growth challenges to tackle, emotivedynamics such as anxiety, relationshipsare known to illicit varied feelings to adolescents (Valkenburg, \& Peter, 2011) as was indicated on Table 4.1.

Table 4.1. Percentages responses on emotional progression factors

\begin{tabular}{lccccc}
\hline Emotional factors & Very positive & Positive & Undecided & Negative & Very negative \\
\hline Anxiety overwhelms me & 20.45 & 18.22 & 47.21 & 14.13 & 0.00 \\
Fear disrupts my thinking & 9.29 & 38.66 & 29.00 & 20.07 & 2.97 \\
'i am loved'... makes me happy & 17.10 & 21.93 & 41.64 & 12.64 & 6.69 \\
Death is my greatest fear & 16.03 & 23.66 & 22.52 & 19.08 & 18.70 \\
Relationships take all my energy & 12.27 & 20.45 & 39.03 & 21.19 & 7.06 \\
I fell nervous when uncertain of things & 9.67 & 16.73 & 32.71 & 26.77 & 14.13 \\
\hline
\end{tabular}


Results from emotional progression factorsrevealed to the present studythat $39.69 \%$ of respondents were positive about death; they confirmed that death was not their greatest fear. The feeling of being loved generated more positive than negative feelings among students. This could be the reason why39.03\% of respondents said that the sense of being loved made them happy compared to $19.33 \%$ of them who considered it asa negative progression factor. Although $39.03 \%$ of the respondents remained undecided on whether relationships take all their energy, over a third (32.72\%) of them agreed that issues of relationships take agreat toll on their lives. Ashwalt, (2011) who looked at viewsof relative magnitudes and patterns of emotional change over a period of three years' of postloss grief indicators found that emotional identification of the normal stages of grief following a death from natural causes enhanced understanding of how the average person emotionally processed the loss of a family member. Cerel, et al, (2006) agreed that adolescents understood and responded to emotional progression factors, especially affection. But Myers, (2006) disagreed when he reported that the nature of death and the underlying circumstances dictated the emotional impact of loss on progression factors.

Qualitative data from interviews and focus group discussions revealed to the present study that, emotions influenced adolescents perception of self, others and issues related to their losses. With nothing else to hang on to, several adolescents sought to cry, be deviant, defy rules and regulations and hurt those in authority as a way to release the pain they felt. Qualitative data was obtained from interviews with selected adolescents on emotional progression factors that influenced their adjustment to loss and grief. The reported themes were on foster parenting, broken relationships, autocratic parenting style, sibling rivalry, feelings of void, birth narrations, reckless lifestyle and mistreatment by guardians.

Foster parenting refers to a person who acts as parent and guardian for a child in place of the child's natural parents but without legally adopting the child. Foster parenting, living with step parents and broken relationships are a reference that mean living with someone who is not a biological parent or that their union was strained and they separated (Hoy, 2012). A study respondent who was a teen growing in the hands of foster parents had never known that the people he dearly referred to as 'dad and mom' had nothing to do with his birth. 'Mother' was in real sense aunty while 'dad' was his aunt's husband. The death of his 'dad' made a relation reveal that vital information to him. It was important to note that the intensity with which he mourned the loss of his father was what prompted the relation to reveal the truth. This was meant to lessen his pain. instead, the respondent was emotionally devastated when he discovered that these were not his real parents as he retorted:

\footnotetext{
... I cried, it pained me that I did not belong... I dream of him...I had cried, but I cried the more when I realized that the dead man who had loved me like his own was not my dad at all...then where was my real dad?...was he dead too...?[Promise]
}

The orphan recounted how he cried because he was pained to discover that he was an outsider where he had all along thought he belonged. He was hurt because he now felt hollow and had to start on an involuntary journey of searching for his biological father-a sense of belonging. This finding agreed with Ashwalt, (2011) that adolescents are extremely sensitive to their parental background. Adolescents are broken at the discovery of a questionable family background, broken family or a form of unfavourable family history. Cook, Deng \& Morgano (2007) also agreed that adolescents are keen on the nature of family background, not that it mattered to an adolescent but that it was a safe base for their emotional satisfaction of a genealogy.

Broken relationships mean that a once flourishing relationship breaks and the spouses start new lives elsewhere with new sets of people or decide to leave alone with their children (Ellis \& Lloyd-Williams, 2008). As parents develop new relationships, adolescents are caught in their arrangements. In some cases, adolescents are not made aware that they are living with foster parents until a naughty relative spilled the beans on them. Broken relationships therefore become an emotional progression factor for adolescents. Reflections of the respondent show that he was pained to know he was living with a step father until he was 15 . His pain was twofold: attachment and the death of his biological father just when he thought he had found him. Similar sentiments were narrated by another respondent who had never seen his biological mother much as he had been told severally that she was alive. He was emotionally upset and was craving for motherly affection.

The excerpts from interview transcripts are as follows:

...I was anxious and excited to meet him ...I was devastated, I cried like a baby....was dumbfounded...[Fortune]

...i am never the same ... I long to see her, I cry, the pain of living with step-mom while she is alive is hurting...[Enabler] 
The adolescents are yearning for parental affection, identity and attachment. Motari, (2006) also concurs that indigenous volitions of death in Western Kenya were due to either punishment by a superior being or a form of destiny. The elders grieved death more because they formed possible explanations that were emotionally attached to death.

Autocratic parenting style refers to a situation where parent's think for their children, give instructions and not suggestions with no room for personal input from adolescents (Piko \& Balazs, 2012). Such parenting style holds that parents' word was followed to the letter without questioning. These autocratic parents hold the notion that children are children, they have no feelings and should not present their point of view. To them, parents are think tanks for children who should be purely implementers. Others may decide to suggest how things are supposed to be done and set up a few house norms with explanations. It was in this context, that parenting style had been identified as a progression factor for adolescents. Most respondents have suffered complicated emotional loss in the hands of their surviving parents. A respondent's mother and uncles decided to bury her father while she was sitting end of year exams. She has been struggling with the pain of having been denied the chance to pay her last respects to a person that was so dear to her. She was emotionally devastated as she was least prepared for that type of news. Her pain was worsened when her mother told her that it was the best option for her to finish her exams.In an incident related to parenting style, adolescents emotionally grieved for parents who are alive but are not available for their emotional needs and sense of belonging. A respondent who had a high esteem for his father was only left yearning for him because of alcohol. For as long as he can remember, he only saw 'the father's hand' as he gave him his money for transport to school and lunch. The father drinks and therefore got home late when respondent is already asleep and respondent leaves for school when dad is still asleep as narrated by respondents;

...dad was and always will be my best friend...I was denied dad's burial...[Joyful]

... i miss my dad a lot, he's alcoholic...[Restored]

These excerpts revealed adolescents' emotional reflections on how they hurt when parenting was not right according to the adolescent the reflections communicate pain that may interfere with adolescent's progression. Sebastian, Burne \& Blakemore, (2008) agreed that parenting was one of the strongest pillars of self-esteem for adolescents. And that lack of it like in the case of the present study would probably dent an adolescents' emotional progression. Autocratic parenting style was also revealed when a grandmother whom the study respondent loved dearly fell sick, died and was about to be buried but the granddaughter who she was named after and felt so attached was not aware. She accidentally heard her father talk on phone to his friend as the funeral arrangements took shape, all in the name of not interfering with her studies. The respondent was also told that death and burials were issues that only affected adults:

\section{...I wept, mourned for my friend and namesake...[Kindness]}

The respondent felt insecure and inadequate because of the parents' action. The respondent felt that there was a disconnect in the way the respondent's parents handled the death of her grandma. The way in which her parents felt about the loss in relation to her. Parental influence was noted as a key progression booster for adolescents as was noted by Negriff, Susman \& Trickett, (2011) who traced truancy, delinquency and early sexual activity to autocratic parenting. Consolvo, (2012) agreed that successful adolescents were built through enhanced coordination and talk therapy.

Feelings of void refer to emotional emptiness in the presence of physical, social and cognitive comfort. Respondents in that state are left wondering how it could be that they are the ones in pain amidst all the merry around them (America, 2012). The study respondent was caught in such an emotional distress when he lost his babyhood significance to fire. Feelings of void were sparked when he got home and found all the other siblings clutching to what they valued most. Emotions overwhelm him as he narrates how amongst his siblings, he was the one without babyhood attachment;

... the feeling is hollow, like a free flow fall...I hurt...no one seemed to care for how I would feel...they don't care... [Faithful]

The study respondent narrated his emotional hurt and emptiness at the realization that his loss was permanent. The adolescent was not able to find a replacement for his lost babyhood treasure. His pain was made real when he noted that the others were able to rescue what mattered to them while he did not as he was in school.The findings agree with Robyn, (2014) who reported that emotion progression defects are very powerful and could make or break an adolescent 
depending on how the exhibited emotions are handled. This was also echoed by Adams, (2012) who noted the complicated emotional family dynamics in the effects of loss of a family member and the resultant grief. But Choi et al, (2007) disagreed that adolescents have a macro system in which they manage their emotional progression factors that was alien to adults.

Comparing nature and nurture refers to an insight in to what nature gave naturally and what nurture gives as the resultant product from environmental influence. Respondents exposed negative manifestations if nurture was negatively emotional. Nature and nurture also refers to the effects of biology and social systems on individuals and their behavior. 'Nature' believes that people are shaped primarily by genetics and biology while nurture' argues that our participation in social life was the most important determinant of who we were and how we behaved (Doughty et. al, 2006). At thirteen years, an adolescent undertook a tree climbing adventure. She accidentally fell and suffered multiple fractures. Poor management led to amputation of her left leg. She shuttles between her loss and her dreams-because in her dreams, she can walk, run and play but reality presented a rude shock as she recited:

\section{I get horrified when I wake up to no leg, I cry, I have not accepted, I cry until I sleep, am happier asleep...[Nice]}

The respondent reported that it was hard to marry reality with her dreams. Her biggest struggle comes when her dream world (nature) presents her with legs where she can run, play dance and go everywhere with her friends, while nurture saw her left back as her friends went out to play, run, dance and cause mischief, like she enjoyed. Ifedigbo, (2008) concurred thatwhen adolescents are made to indulge in comparisons of segments of their life, they stagnate in progression thereby developing problems for themselves and the people around them. Muchai, Ngari \& Mumiukha (2014) also added that when nature and nurture posed a crisis, an adolescent suffered more than an adult because of emotional repression that was very prominent in adolescents. Craig \& Dunn, 2009 also agreed that culture and family background were significant sources of emotional strife for individuals' adjustment to loss and grief. Yet Friedkin\& Johnsen, (2011) differed that social influence networks were well refined and understood by members of a particular society and may not cause emotional stress to individuals' adjustment to loss and grief.

Reckless adolescent lifestyle refers to the adolescent's egocentric personal imagination, their conviction that their thoughts and feelings that they considered unique and should not be tampered with. They engage in sensation seeking which at times put them in trouble with self and others (Jenkins, 2007). They may drink and drive, shout, scream and shout their heads out, or engage in sex without contraception. Reckless adolescent lifestyle was the other emotional factor in adjustment to loss and grief where a female respondent lost her womanhood to adolescence trial and error lifestyle. The shock resulted in her mother's paralysis and a resultant condemning relation that referred to her as a 'bad girl:'

\footnotetext{
...I am bitter with self and others, I regret my action, I cry for my mother's health...my womanhood too...the romours hurt me so much...the pain is everywhere I go, in the house as I see my mother wasting away to paralysis, in my mind, on my body... when I see the operation scars...everywhere...[Graceful]
}

The respondent's reflections was a wakeup call to the lifestyle that she chose but now regrets what has caused her triple pain. The respondent feels bitter with self and others because she felt stuck with that reckless adolescent lifestyle because of the outcome. Pomeroy \& Garcia (2011) agreed that adolescents found it hard to forgive mistakes they did to 'self' as they held themselves accountable both consciously and unconsciously. Santrock \& Mitterer, (2006) also agreed that adolescents felt a lot of pain when they are responsible for their own crisis. However, Valkenburg \& Peter, (2011) disagreed that much as the general belief was that adolescents were hurt more by self inflicted problems, online communication revealed that adolescents use blame game a lot to shift their source of crises to either parent, society, teachers or significant other.

\section{Concluding Remarks}

The findings revealed that emotional progression factors effected adolescents' adjustment to loss and grief. Quantitative findings on emotional progression factors revealed that, respondents were positive about death and they concluded that death was not their greatest fear. Yet, the feeling of being loved generated more positive feelings among adolescent respondents who said that the sense of being loved made them happy. Qualitative findings on emotional progression factors concluded that emotions influenced adolescents perception of self, others and issues related to their losses. The findings reported emotional themes as broken relationships, autocratic parenting style, sibling rivalry, feelings of void, birth narrations, reckless lifestyle and mistreatment by guardians. 
Based on the findings of the study there are various implications: First, schools should strengthen peer counselling among students in their respective schools so as to cater for emotions related to loss and grief. This is because the study found out that most orphaned students sought peer support from fellow students. Secondly, schools should assign trained teachers who can suffice as adoptive parents thereby taking the role of the dead parents while they are in school. This is because some of the orphaned students spend all their valuable time drowned in their emotional progression factors at the expense of growth and academic achievement.

\section{References}

Aaron, F. \& Aaron, B. M. (2005).Psychology's Progress and the Psychologist's Personal Experience. London: Routledge.

Abdulaziz, I. \& Umar, H. (2015). Amnesty: Nigeria's massacre deadliest in history of Boko Haram. Associated Press. Retrieved from http//www.usa.com/story/news/world/book-haram/nigeria-massacre on 9th January, 2015.

Adams, A. (2012). Death at a young age: Family dynamics at the experience of death of a young one. Retrieved from http//www. onpoitnt.wbur.org/sorority-deaths on 30th January, 2014.

America, H. F. (2012). Grief. Hospice Foundation of America: Retrieved from http://www.hospicefoundation.org/grief on March 15th, 2012.

Angela, O. (2014). Adolescent Social Development:Adolescents and Peer Pressure."Retrieved from http://www.sitemaker.umich.edu/ University of Michigan. on October 6, 2014.

Ashwalt, A. (2011). Emotions in Adolescents: Adolescent Emotional Development-A Decade in Review. Journal of Research on Adolescence, Vol. 21 (1), 180-195.

Berk, L. E. (2009). Child Development. (8th ed). United States of America: Pearson Education, Inc.

Bonanno, G. A., Wortman, C. B. \& Lehman, D. R. (2007). Resilience to Loss and Chronic Grief: A Prospective Study from Prelossto 18Months Postloss. PersSocPsychol;Vol. 83, 1150-1164.

Bragg, S. M. (2011). Wiley GAAS 2012: Interpretation and Application of Generally Accepted Accounting principles. Canada: Wiley Publishers.

British Association of Counselling \& Psychotherapy (2009). Adolescence; Peer Therapy Techniques Vol 19. (6). 13-19.

Cerel, J. F., Mary A.; Verducci, J. W., Ronald A. \& Weller, E. B. (2006). "Childhood Bereavement: Psychopathology in the two Years Postparental Death". Journal of the American Academy of Child \& Adolescent Psychiatry; Vol 45 (6), 681-690.

Charach, A. E., Yeung, T. C. \& Lillie, E. (2011). Childhood attention-deficit/hyperactivity disorder and social disorders: comparative metaanalyses; Journal of the American Academy of Child and Adolescent Psychiatry, Vol. 50, (1), 9-21.

Choi W. S., Ahluwalia J. S., Harris K. J. \& Okuyemi K. (2007). Adolescence Progression to Established Delusion: the Influence of Grief.USA: Word Inc.

Choudhury, S. Blakemore, S. J. \& Charman, T. (2006). Social cognitive development during adolescence. Social Cognitive and Affective Neuroscience Vol. 1 (3): 165-174.

Ciacco, J. A. (2008). The Colors of Grief: Understanding a Child's Journey Through Loss from Birth to Adulthood. London: Jessica Kingsley Publishers.

Consolvo, C. (2012). Building Student Success through Enhanced Coordinated Student Services. Journal of College Student Development, Vol. 3 (3):284-287.

Cook, T. D. Deng, Y. \& Morgano, E. (2007). "Friendship Influences During Early Adolescence: The Special Role of Friends' Grade Point Average". Journal of Research on Adolescence. Vol. 17 (2): 325.

Corey G, (2005). Theory and Practice of Counseling Psychotherapy. (6th Ed) Pacific Groove: Brooks Cole.

Creswell, J. W. \& Plano-Clark, V. L. (2011). Designing and Conducting Mixed Methods Research (2 $2^{\text {nd }}$ ed.). Thousand Oaks, CA: Sage Publications.

Currie, J. \& Thiele, B. (2009). 'Globalization and Adolescence: Work and Culture in Societies'. In: A. Brooks, and A. Mackinnon, (Eds.): SRHE, Open University.

Ellis, J. \& Lloyd-Williams, M (2008). "Perspectives on the impact of early parent loss in adulthood in the UK: Narratives Provide the Way Forward". European Journal of Cancer Care: Vol. 6, 317-318.

Engler, (2008). Personality Theories: An Introduction. Cengage Learning. p. 151.ISBN 978-0-547-14834-2

Erikson, E. H. (1968). Identity: Youth and Crisis (2nd Ed.) New York: Norton Print.

Friedkin, N. E., \& Johnsen, E. C. (2011). Social Influence Network Theory: A Sociological Examination of Small Group Dynamics. Cambridge University Press. Retrieved from http://dx.doi.org/10.1017/CBO9780511976735 on 23rd November, 2014

Gathara, P. (2014). Why does the loss of some lives merit more grieving than the loss of others? Retrieved from http//www. islamicdailynews.com/losts-lives-merit-merit-grievingon 13th November, 2014.

Gray, H. D. \& Tindall, J. A. (2008). Peer Counselling: In-depth Look at Training Peer Helpers. Muncie, IN: Accelerated Development.

Gross, R. (2005). Psychology: The Science of Mind and Behaviour.(5th Ed). London: Green Gate Publishing Service.

Hall, V. (2006). Walking on the Ceiling: A study of Adolescent's Management of Crisis in Education. London: Paul Chapman.

Hoffnung, S. (2007). Child and Adolescent Development. (5thed). Bostom: Houghton Mifflin.

Hoy, G. W. (2013).Do Funerals Matter? The Purposes and Practices of Death Rituals in Global Perspective: Retrieved from http//www. deathandrituals.html on 22nd October, 2014. 
http://help.fortroubledteens.com/the-danger-of-treating-teens-like-children.htmlThe danger of treating teens like children. (Retrieved on Friday, $21^{\text {th }}$ February, 2014

Ifedigbo, N. S. (2008). The problem of Adolescence:Excerpts of a lecture delivered at the 2008 Annual Knights of St. John International Cadets and Junior Auxiliaries Convention holding at the KSJI Temple, Our Lady Queen of Nigeria Pro-Cathedral Garki -Abuja. Retrieved from http//www.adolescence.html on $12^{\text {th }}$ November, 2014

Jenkins R. R. (2007). The Epidemiology of Adolescent Health Problems. In: Kliegman R. M. , Behrman R. E., Jenson H. B \& Stanton B. F., eds. Nelson Textbook of Pediatrics. 18th Ed. Philadelphia, Pa: Saunders Elsevier; chap 110.

Jose P. E., Kljakovic M., Scheib E., Notter O. (2012). 'The Joint Development of Traditional Bullying and Victimization with Cyber Bullying and Victimization in Adolescence'. Journal of Research on Adolescence Vol.22 (2): 301-309.

Kamau, G. W. (2011). Adults' perspectives on loss and grief: A case study of Kiambu Municipality, Kenya.URI: Retrieved from http://irlibrary.ku.ac.ke/handle/123456789/2103 on 4th January, 2014.

Kübler-Ross, E. (2005) On Grief and Grieving: Finding the Meaning of Grief through the Five Stages of Loss. Simon \& Schuster Ltd, ISBN 0-7432-6344-8

Leek, O. L. (2011). "School-based Support Groups for Traumatized Students". School Psychology International. Vol. 32 (2), $163-178$.

Lucas, S. R. (2013). "Beyond the Existence Proof: Ontological Conditions, Epistemological Implications, and In-Depth Interview Research.", Quality \& Quantity. Vol 19 (7) 432-439. doi:10.1007/s11135-012-9775-3.

Marshall, H (2010). "Midlife loss of parents: The Transition from Adult Child to Orphan". Ageing International. Vol. 29 (4), $351-367$.

Mason, M. (2010). Sample Size and Saturation in PhD Studies Using Qualitative Interviews. Forum Qualitative Sozial for Schung I Forum: Qualitative Social Research, Vol. 11 (3), Art. Retrieved from http://www.nbn-resolving.de/urn:nbn:de:0114-fqs100387 on March 23rd 2014 ,

Motari, S. N. (2006). Perspectives and Indigenous Volitions of Death and its Origin among the Communities of Western Kenya. Unpublished Masters Thesis, Kenyatta University.

Muchai L., Ngari S. \& Mumiukha C. (2014).The Influence of Perceived Post Election Violence on Emotional Well Being among Secondary School Students in Nakuru County, Kenya. International Journal of Innovative Research and Development Vol.3 (3) $126-135$

Murdin, P. (2009). Full Meridian of Glory: Perilous Adventures in the Competition to Measure the Earth. Journal Springer. Vol.1 114-118. ISBN 978-0-387-75533-5

Myers, E. (2006). Teens, loss, and grief: The Ultimate Teen Guide. Lanham, Md.: Scarecrow Press Pacific Grove: C A Brooks/Cole

Negriff, S., Susman, E. J. \& Trickett, P. K. (2011). The Developmental Pathway from Pubertal Timing to Delinquency and Sexual Activity from Early to Late Adolescence. Journal of Youth and Adolescence40 (10): 1343-1356.

Neil, J. (2009). Peer Counselling Training Manual. Electric Journal of Peer Counselling, Vol.106, 571-577.

Nyangaga, J. A. (2007). Adolescents in School Leadership: Exploring Students' Experiences in Becoming School Leaders. Unpublished MA Thesis. Karachi: The Aga Khan University.

Okello, L. N. (2008). A Study of Adolescent Development Problems Among Girls in Secondary Schools. A case Study of Siaya and Kisumu Districts. Unpublished Master of Education Thesis: Kenyatta University.

Owaa, J. (2010). Impact of Peer Counselling on Student Discipline in Public Secondary Schools of Kisumu Municipality. Unpublished Master of Education Thesis: Maseno University.

Owuor, B. W. \& Mauta, S. (2011). Strengthening Sustainable Adaptation: Examining interactions between Pastoral and Agropastoral Groups in Dryland Kenya. Climate and Development, Vol.3 (1), $42-58$.

Pelt, N. V. (2005). Heart to Heart-The Art of Communication. (11 th Ed.), Houghton: Editorial Sufeliz.

Petersen, M. (2012). Victims to survivors: Liberians' experiences and resilience during Liberian civil war. Master of Social Work Clinical Research Papers. Paper 128. Retrieved from http://sophia.stkate.edu/msw_papers/128 on 21st January, 2015.

Piko, B. F. \& Balazs, M. A. (2012). Authoritative parenting style and adolescent smoking and drinking, Addictive Behaviors. Vol. 37, (3). pp. 353-356,

Pomeroy, E. C., \& Garcia, R. B. (2011). Children and Loss: A Practical Handbook for Professionals. Chicago, III: Lyceum Books.

Robyn, D. (2014). Ebola Orphans in West Africa struggle to cope with losses. Retrieved from http//www.latimes.com/africa/la-fg-liberiaebola-orphans on 13th November, 2014.

Rossi, C. \& Rossi, P. A. (2005). Adolescence - When Does It Begin and End. New York: Cambridge University Press.

Rothbauer, P. (2008). Triangulation. In Given, L. (Ed.), The SAGE Encyclopedia of Qualitative Research Methods. Sage Publications. pp. 892-894.

Santrock, J. W. \& Mitterer, J. O. (2006). Psychology (3rd Ed.) Toronto: McGraw-Hill Ryerson.

Santrock, J.W. (2007). A Topical Approach to Life-Span Development. New York: McGraw-Hill.

Scharf, M. \& Shulman, S. (2010). Adolescents' socio-emotional competence and parental representations of peer relationships in adolescence- A Paper presented at the Society for Research on Adolescence, Boston: Fireworks Press.

Sebastian C., Burnett S. \& Blakemore S. J. (2008). Development of the self-concept during adolescence. Trends in Cognitive Sciences; Vol.12:441-446.

Stake, R.E. (2010). The point of triangulation. Journal of Nursing Scholarship,Vol. 33(3), 254-256. Retrieved from: http://www. ruralhealth. utas.edu.au/gr/resources/docs/the-point-of-triangulation.pdf.on 11th December, 2013

Taylor, O. D. (2011). Adolescent depression as a contributing factor to the development of substance use disorders; Journal of Human Behavior in the Social Environment, Vol. 21, (60), 696-710. 
Tharp-Taylor, S., Haviland, A. \& D'Amico,E. J. (2012). Victimization from mental and social disorders in early adolescence; Adolescent Behaviors, Vol. 34, (6-7), 561-567.

Valkenburg, P. M. \& Peter, J. (2011). Online Communication Among Adolescents: An Integrated Model of Its Attraction, Opportunities, and Risks.Journal of Adolescent Health, Vol.48 (2), 121-127.

Valkenburg, P. M. \& Peter, J. (2011). Online Communication Among Adolescents: An Integrated Model of Its Attraction, Opportunities, and Risks.Journal of Adolescent Health, Vol.48 (2), 121-127. 